\title{
Numele proprii în notele marginale dintr-o traducere românească a Vechiului Testament din secolul al XVII-lea (ms. 4389 B.A.R.)
}

\author{
Ana-Maria Gînsac, Mădălina Ungureanu * \\ Institutul de Cercetări Interdisciplinare, Departamentul Științe Socio-Umane, Universitatea „Alexandru Ioan Cuza”, \\ Bd. Carol I 11, 700506 Iași, România
}

\author{
Despre articol \\ Istoric: \\ Primit 14 august 2019 \\ Acceptat 19 august 2019 \\ Publicat 7 noiembrie 2019 \\ Cuvinte-cheie: \\ vechea română literară \\ text biblic \\ traducere \\ glose \\ onomastică
}

\begin{abstract}
Rezumat
Primele traduceri ale Bibliei în limba română prezintă numeroase probleme în privința traducerii numelor proprii din textele sursă. Unele dintre acestea sînt rezolvate în text, altele pe marginea lui. În privința acestei clase nominale, glosele sau notele marginale dintr-un text manuscris din secolul al XVII-lea care conține a doua traducere integrală a Vechiului Testament în limba română (manuscrisul românesc nr. 4389 de la Biblioteca Academiei Române) privesc raportul textului tradus cu sursa principală (corectarea unor erori de traducere), cu sursele secundare (semnalarea unor realități denominative diferite de sursa principală) și cu norma lingvistică a textului tradus (adaptări morfologice sau lexicale, actualizări potrivit sistemului denominativ al limbii țintă). Ne propunem să urmărim specificul problemelor legate de transpunerea în limba română a onomasticii biblice pe baza tratamentului acesteia în notele marginale din textul amintit și să clarificăm, în măsura posibilului, pe baza informațiilor obținute, unele aspecte legate de sursele utilizate și de modul în care traducătorul se raportează la acestea.
\end{abstract}

\section{Preliminarii}

Primele traduceri integrale ale Vechiului Testament în limba română și prima versiune românească integrală a Bibliei fac din secolul al XVII-lea o perioadă fastă a culturii române, atît din punctul de vedere al producției în sine (cultura română se racorda, astfel, la starea europeană de lucruri), cît și din cel al metodei utilizate în traducere. Primele versiuni românești ale textului creștin fundamental se caracterizează, astfel, prin utilizarea mai multor izvoare. Departe de a constitui reproduceri fidele ale unui singur original, ele indică efortul traducătorilor de a valorifica mai multe versiuni, cu scopul de a obține un text, pe de o parte, cît mai limpede, pe de alta, cît mai acceptabil din punct de vedere canonic. Fiecare versiune biblică (fie ea vetero- sau nou-testamentară) se sprijină pe texte anterioare și pe surse multiple (Andriescu, 1988, p. 14-17). Nicolae Spătarul Milescu, se arată în Cuvîntu înnainte cătră cititori (MS.45, 456 ${ }^{\mathrm{r}}-457^{\mathrm{v}}$ ), unde este invocată chiar prefața lui Milescu din manuscrisul său pierdut, a avut drept sursă principală un text grecesc (SEPT.), dar a folosit și alte surse: un text slavonesc (OSTR.) ${ }^{1}$ și izvoare latinești; revizorul traducerii utilizează (este drept, constrîns de lipsa izvorului principal al lui Milescu) și o altă sursă grecească (SEPT.1653), iar pentru consemnarea locurilor paralele preia trimiterile biblice marginale din versiunea biblică slavonă. Traducătorul versiunii din MS.4389 folosește, pe lîngă sursa principală (OSTR.), un text latinesc și traducerea lui Milescu, așa cum arată în Cuvînt înainte cătră cetitor, p. 1-2².

\footnotetext{
*Adrese de corespondență: anamaria.gansac@gmail.com(AMG),madandronic@gmail.com (MU).

${ }^{1}$ Cu privire la traducerea slavonească a Bibliei, vezi Thomson (1998).

${ }^{2}$ Andriescu (1988, p. 15, 17) vorbește despre similitudinile dintre Palia de la Orăștie (PO) și versiunile biblice ulterioare: „Astfel de apropieri formale de Palia de la Orăștie, până la forțarea unor explicații, ne dovedesc, dacă mai era nevoie, că traducătorii români de texte religioase din a doua jumătate a secolului al XVII-lea, întocmai ca înaintaşii lor din prima jumătate şi din secolul anterior, își alcătuiau noile traduceri sprijinindu-se pe toate textele anterioare”. El are în vedere un context din $F a c, 3,8$, care sună astfel: „Dumnezeu îmblă în rai la răcoare după amiadzădzi” (PO), „Și auziră glasul Domnului Dumnedzău
} 
Ana-Maria Gînsac, Mădălina Ungureanu

\subsection{Despre a doua traducere integrală a Vechiului Testament în limba română}

Ms.4389 de la Biblioteca Academiei Române ${ }^{3}$ conține textul Vechiului Testament tradus în limba română după textul slavonesc al Bibliei de la Ostrog, 1581 (OSTR.): „Iar totuși mai mult ne-am ținut de izvodul cel slovenesc și de care am umblat mai aproape de dînsul" (Cuvînt înainte cătră cetitor, p. 2). Ca surse secundare, traducătorul a utilizat o versiune latină a Bibliei, Biblia ad vetustissima exemplaria castigata, tipărită la Antwerp, în 1565, sau o versiunea ulterioară (Andriescu, 1988, p. 14), iar pentru comparația cu textul grecesc, traducerea (nerevizuită) realizată de Nicolae Spătarul Milescu (Ursu, 2003, p. 41). Referitor la ponderea în traducere a acestor surse, Cândea (1979, p. 132) consideră că „traducerea este copia românească a acestui model [i.e. OSTR.], cu unele influențe din manuscrisul spătarului", criteriu de la care traducătorii „s-au abătut uneori”. Manuscrisul, descoperit în 1915 (Cândea, 1979, p. 107, nota 5), i-a fost atribuit lui Daniil Panoneanul pentru prima dată de Al.T. Dumitrescu în 1916 (Ursu, 2003, p. 30). Discuția a fost reluată de Ursu (2003), care a adus o serie de argumente întemeiate în acest sens. Tot Ursu (2003, p. 38) datează traducerea între 1665-1672 și copierea textului (el consideră, cu argumente, că manuscrisul este autograf) între 1673-1679. Cândea (1979, p. 131) propune aceeași dată pentru traducere. Textul integral al manuscrisului a fost publicat în transcriere interpretativă însoțită de facsimil în seria MLD (1988-2015).

Relația dintre primele traduceri românești ale Vechiului Testament este limpede: Nicolae Spătarul Milescu a făcut prima traducere, care nu s-a păstrat; această traducere a fost utilizată (nu știm în ce împrejurări) de Daniil Panoneanul (dacă acceptăm paternitatea propusă de Ursu, 2003) pentru versiunea din MS.43894. Versiunea revizuită (nu se știe de cine; Ursu, 2003, p. 441, consideră că acest revizor a fost Mitropolitul Dosoftei, ipoteză încă insuficient explorată) a traducerii lui Milescu, păstrată în MS.45, a fost supusă unei diortosiri și publicată în Biblia de la 1688 (vezi MLD).

\subsection{Notele marginale în primele traduceri românești ale Bibliei}

Primele traduceri ale Bibliei în limba română conțin pe marginea lor diverse indicații cu rol în rectificarea sau explicarea unor pasaje de text. Variantei textuale, reprezentînd textul tradus propriu-zis, îi sînt aduse, pe margine, observații referitoare la formă sau la conținut, denumite, în literatura de specialitate, "glose” (TTepelea, 1963, p. 274; Șesan, 2002, p. 59; Gafton, 2005, p. 197) sau „note marginale” (Ursu, 2003, p. 32). În studiul de față considerăm cei doi termeni ca fiind sinonimi, renunțînd la a face distincție între notațiile care au rol explicativ, referitoare la conținut (glosa este „o formă perfecționată de împlinire a textului în limba țintă. Forme și structuri proprii acesteia se concentrează asupra cîte unui conținut din limba sursă în scopul redării deslușite a respectivului conținut [...]”, Gafton, 2005, p. 44) și celelalte (trimiteri biblice, indicații tipiconale etc.). În fond, rolul tuturor notațiilor marginale este acela de a completa textul, de a-l face inteligibil cititorului, de a direcționa și optimiza receptarea lui. Acest procedeu al notațiilor marginale le-a servit, așadar, traducătorilor la explicarea, traducerea sau substituirea unor termeni (culturali, doctrinali, regionali etc.) mai puțin cunoscuți și a unor cuvinte sau fragmente neclare, precum și la soluționarea unor probleme legate de forma mesajului transmis (corecturi ortografice, completări, inversări de topică etc.). De asemenea, pe marginea textului au fost inserate variante de echivalare specifice diverselor surse utilizate în traducere.

Tipologia notelor marginale în primele secole ale scrisului în limba română depinde de specificul fiecărui text în parte, de scopul traducătorului și de concepția lui despre actul traducerii, de sursele utilizate, de cititorul căruia i se adresa. Roques (1908, p. xliii) identifica în Palia de la Orăștie (PO), prima traducere cunoscută în limba română a Genezei și Exodului, diverse tipuri de „notații marginale” sau „glose”, pe care

îmblîndu în grădină în desară” (MS.45), „Și auziră glasul Domnului Dumnezeu umblînd în raiu în deseară” (MS.4389, care glosează marginal locuțiunea în deseară prin amiază). Această glosă este considerată de Andriescu o preluare grăbită a formei din PO; de fapt, aceasta se explică prin reproducerea lecțiunii din OSTR. (въ non8 AN̂), în timp ce în text este preluată cea din MS.45; cf. post meridiem (vULG.).

${ }^{3}$ Vezi descrierea manuscrisului la Ștrempel (1987, p. 438-439).

${ }^{4}$ Întrucît textul tradus de Milescu nu s-a păstrat, utilizăm pentru comparație versiunea revizuită a acestuia din MS.45. 
le clasifica astfel: „a) les unes sont des explications de mots et doivent appartenir en propre au traducteur roumain; b) d'autres sont destinées à faire connaître ou à expliquer des mots hébreux; c) quelques-unes enfin sont de véritables commentaires du texte”. Potrivit lui Țepelea (1963, p. 281-282), în Noul Testament de la Bălgrad (1648), „glosele” de pe marginea textului aduc informaţii privind sursele utilizate de traducători și nivelul pregătirii lor cărturărești; ele sînt importante pentru datarea pătrunderii în limbă a unor neologisme, precum și pentru determinarea poziției unor termeni în limba română la momentul efectuării traducerii. Glosele marginale din prima traducere integrală a Noului Testament în limba română au fost studiate din perspectiva sinonimiei și a seriilor sinonimice de Șesan (2002, p. 59). O sistematizare a gloselor din Biblia lui Samuil Micu (1795) se găsește la Catană-Spenchiu (2013). Întrucît notele sînt o componentă importantă a textelor din perioada veche a scrisului românesc, ele au generat o literatură de specialitate bogată (vezi Gafton, 2012, p. 329, nota 282; Soare, 2015, p. 3, nota 4; Merlo, 2018, p. 658).

Elaborată pe baza unui inventar bogat de exemple selectate din textele biblice românești ale secolului al XVI-lea și întemeiată pe principiul ,înțelegerii depline a textului” în limba țintă, tipologia propusă de Gafton (2005, p. 196-268) conține două tipuri de „glose”, după funcțiile pe care le au în text: a) glose referitoare la forma textului (trimiteri biblice, indicații tipiconale, trimiteri la izvoare, sume); b) glose referitoare la conținutul textului (fragmente de text omise, variante de traducere, sinonime, dezambiguizări prin trimiteri la persoana/ locul la care se face referire în text, explicații ale unor fragmente scurte, restrîngerea unor sensuri sau lărgirea lor etc.).

Despre notele marginale din primele traduceri românești ale Vechiului Testament a vorbit N.A. Ursu, care le-a luat în discuție în argumentarea paternității lui Dosoftei asupra reviziei traducerii Vechiului Testament efectuate de Milescu (Ursu, 2003, p. 443-445) și a paternității lui Daniil Panoneanul asupra traducerii păstrate în MS.4389 (Ursu, 2003, p. 91-96). Intr-o încercare de sistematizare a gloselor din MS.45, Gînsac (2013) identifică: note privind morfologia textului și note lexicale (explicații ale terminologiei folosite; explicații ale calcurilor din text; sinonime care rezolvă diferențele de ordin diatopic dintre traducere și revizie; sinonime care oferă variante de traducere sau sînt mai adecvate sensului din original). O încercare de tipologizare a notelor din două cărți biblice din MS. 45 se găsește la Ungureanu (2015); fără a fi clasificate, glosele marginale din acest manuscris au fost explicate în MILESCU. De asemenea, Gînsac (2012b) discută câteva dintre glosele referitoare la numele proprii din cele două manuscrise.

Ceea ce uimește în privința notelor marginale din primele traduceri integrale românești ale Vechiului Testament este caracterul lor sistematic, programatic, impresie la care contribuie, pe de o parte, un sistem coerent de marcare a diverselor tipuri de note și, pe de altă parte, explicitarea acestuia în prefețele celor două manuscrise. Comparația dintre cele două indică atît locurile comune, cît și particularităţile fiecărui text. Astfel, o parte dintre notele din MS. 45 privesc diferențele dintre izvoarele grecești utilizate de traducător şi, respectiv, de revizor sau corectarea unor erori de traducere sau copiere; de cealaltă parte, traducătorul textului din MS.4389 consemnează marginal diferențele dintre izvoarele utilizate sau, cleric fiind (Cândea, 1979, p. 129), atrage atenția asupra semnificaţiilor morale ale unor pasaje biblice. În privința glosării numelor proprii, Gînsac (2012a, p. 225-226) constată, de asemenea, cîteva diferențe între cele două manuscrise: „din perspectiva glosării numelor proprii, spre deosebire de MS.45, care se caracterizează printr-un literalism extrem faţă de textul Septuagintei, fapt indicat de prezența emendărilor aproape exclusiv de tip formal la care sînt supuse numele proprii glosate, MS.4389 compilează sursele, fapt vizibil reflectat de prezența marginală a unor traduceri preluate din alte surse și de frecventele substituiri ale numelor proprii din text prin nume existente în limba română la momentul efectuării traducerii”.

O parte destul de importantă a gloselor marginale din cele două manuscrise biblice sînt referiri de diverse tipuri la numele proprii din text. Transpunerea numelor biblice din greacă sau slavonă în limba română a fost o operație dificilă. În privința Septuagintei, traducătorii s-au confruntat cu numeroasele inconsecvențe (în versiunile folosite de traducătorii/ revizorii români) privind încorporarea în flexiunea greacă a numelor proprii semitice, actualizările culturale ale unor nume proprii sau traducerea formelor descriptive. Acestor dificultăți li se adaugă și faptul că, fiind transpuse pentru prima dată în limba română, numele biblice au pus traducătorilor diferite probleme de adaptare grafică (transcriere și transliterare), 
Ana-Maria Gînsac, Mădălina Ungureanu

morfologică (flexiune) și semantică în limba română (vezi Ana-Maria Gînsac, în MILESCU, p. CCXCICCCXXV). Pornind de la aceste premise, ne propunem să urmărim specificul problemelor legate de preluarea și adaptarea în limba română a numelor proprii biblice pe baza tratamentului acestora în notele marginale din MS.4389 și să clarificăm, în măsura posibilului, pe baza informațiilor obținute, unele aspecte legate de felul în care traducătorul se raportează la surse.

\subsection{Notele marginale din MS.4389}

În general, notele marginale sînt rezultatul unor confruntări: între limbi diferite, între izvoare diferite, între variante dialectale diferite, între dialect și variantă supraregională etc., în funcție de tipul textului, de erudiția traducătorului, de scopul traducerii și de publicul țintă. În prefața MS.4389, traducătorul insistă asupra motivelor care l-au determinat să întreprindă o traducere a Vechiului Testament (lipsa acestui text în limba română, spre deosebire de alte culturi; necesitatea unei versiuni românești; lipsurile traducerii lui Milescu) și asupra izvoarelor utilizate. Folosirea mai multor izvoare este explicată prin dorința de a oferi un text cît mai inteligibil; este metoda pe care o găsește traducătorul pentru a depăși faptul că nu stăpînește desăvîrșit vreuna dintre limbile de cultură; o idee asemănătoare se întîlnește și în prefața la Îndreptarea legii, cu o formulare similară; vezi Ursu (2003, p. 128). Pare că traducatorul își dorește, de asemenea, modernizarea textului biblic utilizat în mod tradițional (după tradiția slavonă), pe de o parte, întrucît adoptă tehnica izvoarelor paralele, și, pe de alta, pentru că adoptă procedeul notării marginale a versetelor și a trimiterilor biblice: „văzînd cum că alte limbi toate de la o vreame încoace scriu cartea legii vechi noao cu stihuri pre margine, pentr-aceaea și noi toată cartea aceasta o am scris cu stihuri la toate capetele, şi cuvintele care sînt și într-alt loc grăite semnate iarăşi la margine, precum iaste la latini, pentru aflarea mai lesne a fiecărui lucru și cuvînt” (Cuvînt înainte cătră cetitor, f. $1^{\mathrm{v}}$ ). În orice caz, scopul este acela de a obține un text funcțional, coerent, adaptat la nevoile utilizatorului. Iar secvențele care i se par acestuia din urmă lipsite de coerență sau, mai degrabă, în dezacord cu aspectul tradițional al textului trebuie puse, spune traducătorul, în primul rînd pe seama izvoarelor: „Deci, o, iubite cetitoriu, cetind cartea aceasta, și ce vei afla într-însa nu bine tălmăcit după pricepînța ta [s.n.], să nu dăfaimi îndată și numaidecît pînă nu vei alătura izvoadele cîte treale de pre care am izvodit noi și am prepus, adecă cel slovenesc și cel lătinesc și cel ellinesc, de pre care au fost prepus cel mai denainte rumânesc" (ibid.).

La fel ca în MS.45, în MS.4389 se folosește un sistem coerent de marcare a diferitelor tipuri de note marginale. Astfel, trimiterile biblice sînt semnalate printr-o linie oblică între două puncte; observațiile marginale personale sînt încadrate, de regulă, între acolade; cuvintele sau sintagmele glosate sînt marcate, atît în varianta textuală, cît și în cea marginală, prin: a) „sile” [ $[`]$ și alte semne: $[\downarrow],[+]$; b) sintagme care

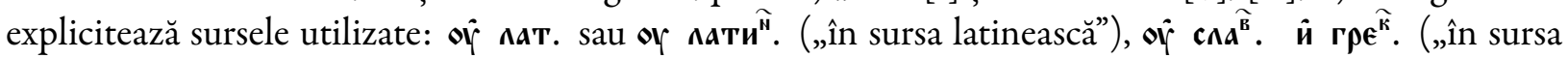
slavonească și în cea grecească”), ồ cnak. (,în sursa slavonească”). Ursu (2003, p. 32-33) consideră că cele mai multe note sînt scrise de la început, cînd textul traducerii a fost copiat de pe ciorne în actualul manuscris, „elegant caligrafiat”. Altele, cu o grafie mai liberă, care rezumă unele pasaje din text, au fost adăugate, probabil, ulterior, de aceeași mînă.

Semnificația „silelor” ( ${ }^{2}$ ), așa cum sînt numite aceste semne în Ms.45, este descifrată în acest manuscris, în Cuvîntu înnainte cătră cititori (ele sînt o contribuție a revizorului): „Iar unde vei vedea acesta ${ }^{\sim}$ deasupra unui cuvînt, cîte vor fi înlăuntru şi afară silele aceastea, acela sau e cuvînt de îndoire, de zice sau aşa, sau aşa, sau el s-au aflat într-un izvod într-un chip, și într-alt izvod într-alt chip și fără bănuială sînt așa” $\left(457^{\mathrm{r}}\right)$. Însă utilizarea silelor nu este specifică numai manuscriselor în discuție; ele apar, cu aceeași funcție de consemnare a variantelor, și în alte texte din epocă, de exemplu, în lexicoanele slavo-române redactate în Muntenia, în a doua jumătate a secolului al XVII-lea. În prefaţa Ms.4389, sistemul de semnalare a notaţiilor marginale este parțial explicitat; explicațiile se referă la introducerea versetelor și la trimiterile marginale, făcute după model latin (Cuvînt înainte cătră cetitor, $1^{\mathrm{v}}$ ).

Dintre semnele care marchează diferitele tipuri de note marginale în MS.4389, unele sînt specializate (cele care indică trimiterile biblice, comentariile sintetice); săgețile și silele sînt folosite alternativ pentru a indica 
fie confruntarea dintre diferitele izvoare, fie pe cea dintre dialecte sau idiomuri (de exemplu, cu scopul de a propune varianta $i i$ pentru dăşărturi, pentru a nota sensul 'parte a abdomenului la animale', la Lev, 3, 4 se folosește o săgeată, dar mai jos, la 3, 10, aceeași operațiune este marcată prin sile).

Referitor la conținutul notațiilor marginale din Ms.4389, Andriescu (1988, p. 16-17) remarca faptul că acestea sînt, de regulă, sinonime românești pentru cuvintele din text sau variante sugerate de compararea surselor utilizate și răspund intenției autorului de a îi înlesni cititorului înțelegerea textului, dar, am adăuga noi, a textului biblic înțeles ca sistem complex, ca juxtapunere de variante și nu ca text individual. Modul utilizării lor reflectă două tendințe ale traducătorului: pe de o parte, acesta conservă tradiția sursei în text, inovînd pe margine, iar, pe de altă parte, inovează direct în text, elementul tradiţional, „devenit explicație”, find notat marginal.

\section{Numele proprii în notele marginale din Ms.4389}

Raportat la subclasele onomastice, majoritatea numelor proprii notate pe margine în Ms.4389 sînt toponime, la care se adaugă uneori derivatele lor etnonimice; un procent mai mic îl reprezintă notele referitoare la antroponime, astronime și crononime. Potrivit rolului lor, raportat la varianta textuală, notele marginale care conțin nume proprii pot fi clasificate astfel: emendări ale variantei textuale în consens cu sursa principală; adnotări aduse variantei textuale în consens cu o sursă secundară; emendări ale variantei textuale în raport cu norma lingvistică; adnotări explicative ale variantei textuale în raport cu sistemul denominativ al limbii române; clarificarea variantei textuale prin comentarii marginale cu caracter enciclopedic.

\subsection{Emendări ale variantei textuale în consens cu sursa principală (OSTR.)}

Acest tip de note se referă la reluarea totală sau parțială, pe margine, a unor nume ilizibile în text, prin: (a) corectarea numelui modificat în text pînă la ilizibilitate prin reluarea sa integrală pe margine; (b) corectarea numelui propriu din text prin reluarea, pe margine, a literelor sau a silabelor scrise greșit în text:

(a)

$\begin{array}{lll}\text { Verset } & \text { Varianta textuală } & \text { Varianta marginală } \\ \text { 1Paral, 8,2 } & \text { Naguil } & \text { Naguil } \\ \text { 1Paral, 27,20 } & \text { Ozai } & \text { Ozai }\end{array}$

(b)
Is.Nav, 15,7
„împotriva apropierii Dominului”
$2 E z d r, 8,42$
Seméia
$D$, cf. Аөми ${ }^{\widehat{\mathrm{N}}}$ (оSTR.)
Corectează litera $m$, scrisă defectuos în text (cf. Ms.45 Sameaas, OSTR. Omêia, vULG. Semei); marcat cu săgeată.

\subsection{Adnotări aduse variantei textuale în consens cu o sursă secundară (VULG. sau MS.45)}

Aceste note sînt cele mai numeroase și sînt rezultatul confruntării dintre izvoarele folosite în traducere. Această inventariere a variantelor de către traducător se explică prin grija acestuia de a oferi un text cît mai complet, ireproșabil, în acord cu toate sursele sale (adică în acord cu toate versiunile textului biblic din limbile de cultură; vezi supra). În unele cazuri, adnotarea marginală prin raportare la o sursă secundară poate avea rol explicativ. Astfel, dacă sursa principală conține un nume opac, redat ca atare în text, nota marginală reproduce o variantă denominativă dintr-o sursă secundară (VULG. sau MS.45) realizată printrun nume transparent, transpus în română prin traducere. În alte cazuri, variantele denominative notate marginal, deși tot opace, erau, poate, mai cunoscute (în virtutea tradiției) decît cele din text, iar notele au, deci, tot rol explicativ. 
2.2.1. Pe de o parte, există adnotări cu menționarea explicită (pentru sistemul de marcare a notelor, vezi supra) a sursei de unde este preluată varianta din notă: (a) varianta este un nume transparent; (b) varianta este un nume opac:

(a)

(1) Amos, 9, $7 \quad$ Vothra, cf. вóspa (osTR.)

(2) $3 R e g, 9,13$

(3) Iez, 25, 13

(b)

(4) $3 \operatorname{Reg}, 4,9$

(5) 2Paral, 36, 20

(6) Neem, 4, 2

(7) Isa, 23, 12

(8) $1 \mathrm{Mac}, 14,27$

(9) $2 M a c, 6,1$

(10) $2 M a c, 6,2$

(11) $1 \mathrm{Mac}, 12,7$ (cf. 12, 20)

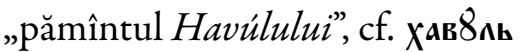
(Ostr.), „Terram chabul” (vUlg.) „vor cădea goniți de la Theman”, cf. oемánъ (OSTR.), MS. 45

„feciorul lui Dacar", cf. с ст'ъ Аакар (ostr.), „fiiul lui Dacar” (MS.45)

„împăratul mideanilor", cf. ми ${ }^{\hat{A}} \mathbf{c k a r o}($ OSTR.), midilor (MS.45)

„putearea lui Somoron”, cf. comópo" (OSTR.), MS.45

„fata Siónului", cf. ciö́na (osTr.), MS. 45

Asaramel, cf. Asaramel (vULG.), Saramel (MS.45)

„un bătrîn oarecarele athinean”, cf. àримеєиима (OSTR.), athineu (MS.45)

„Diia și Olimbiia”, cf. Aï $\hat{\mathbf{n}}$ омимъвїь (ostr.), „Dia cerescului" (MS.45)

„au fost trimease cărți... de Dárie”, cf. w aápïa (ostr.), „de la Dárie” (MS.45)

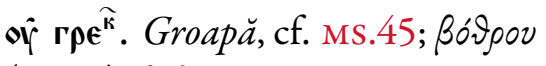

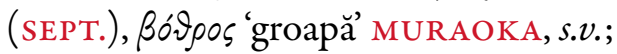

ôे nat. Cyrene [scris cu caractere latinești]

ô гре $\hat{\epsilon}^{\widehat{\kappa}}$. hotarului, cf. Hotar (MS.45),

öplov (SEPT.)

ôे пат. Austru, cf. „faciam eam

desertam ab Austro";

ố пати". Vendacar, cf. Bendecar

ôे $\boldsymbol{\Lambda a}^{\mathrm{T}}$. persilor, cf. „rex Persarum”

ôे $\boldsymbol{n a}^{\mathrm{T}}$. samariteanilor, cf.

Samaritanorum

ồ $\boldsymbol{n} \boldsymbol{a}^{\mathrm{T}}$. Sidónului, cf. „filia Sidonis”

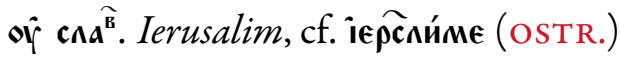

ô $\boldsymbol{n a}^{\mathrm{T}}$. Antiohiiá, cf. „rex senem quemdam Antiochenum"

ô $\boldsymbol{n a}^{\mathrm{T}}$. Iovis [scris cu caractere latinești], cf. „Iovis Olimpii”

of $\mathbf{~ a ~}^{\mathbf{T}}$. Arie, cf. „ab Ario” (vulg.1592, 1603, 1645), dar „a Dario” (vulg. 1565 , 1587).

2.2.2. Pe de altă parte, există adnotări fără menționarea explicită a sursei de unde a fost preluată varianta din nota marginală: (a) varianta este un nume propriu transparent; (b) varianta este un nume propriu opac:

(a)

(1) $1 \operatorname{Reg}, 12,10$

(2) Zah, 14, 4

(3) Is.Nav, 13, 21 „am slujit... lui Astaroth”, cf. âcmapósomz (ostr.), Astaroth (vULG.)

„Muntele Eleónului”, cf. е̇лєóńcmen (OSTR.), „măgura Eleon”, cu glosa maslinilor (MS.45)

„toate cetățile Misórului", cf. гра́ды мисо́ровы (OSTR.), lui Misor (MS.45)
Desişurilor, cf. „și am slujit... Desişurilor"

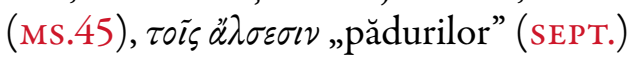

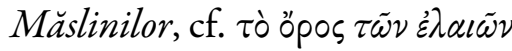
(SEPT.), „Mons olivarum” (vUlG.)

Cîmpurilor, cf. „urbes campestres” (vULG.) 
(4) 1 Reg, 9, 12-13 s.u.

(5) Isa, 19, 18

(b)
(6) Isa, 18, 1
(7) Iez, 30, 14 și 16
(8) Iez, 30, 17
(9) Dan, 10, 4

(10) Naum, 3, 9

(11) 1Paral, 2, 9

(12) 1Paral, 2, 10 „în Váma”, cf. въ вамt (osTr.), (MS.45) „cetatea Asedécului", cf. àcéAєcк' (ostr.), „cetate Asedec” (Ms.45)

"de ceaea parte de Marea Mirei”, cf. рҺкѝ мӥрьски (OSTR.) "cetatea Diósului", cf. Anồck rрáAt (osTr.), Diospólis (Ms.45) "Tinerii Cetăţii Soarelui”, cf. connbya гра́Aa (OSTR.), MS.45 "rîul cel mare care iaste Edechélul", cf. ёАєке́nь (OSTR.), Dechel (MS.45)

Fúdul, cf. $\$ 8_{\mathbf{A} \mathbf{z}}$ (OSTR.), Fud (Ms.45)

Oáram, scris Wápa” , cf. òāpám (osTR.)

\section{Cápa}

Inălțime, cf. excelso (vULG.)

Soarelui, cf. „Civitas solis” (vUlG.);

Ethiópiei, cf. „rîurile Ethiopiei” (MS.45), „trans flumina Atiopic” (vUlg.)

Iliopolii, cf. "Juvenes Heliopoleos” (vUlG.)

Africa, cf. Aphrica (vulg.)

marginal, marcată în text prin semnul

$[\downarrow]$ deasupra lui $\boldsymbol{w}$ și $[+]$ deasupra primului a, corectura $a$, cf. $\delta \dot{\alpha} \rho \alpha ́ \mu$ (sEPT.), Aram (MS.45)

marginal, marcată în text prin semnul $[\downarrow]$ deasupra slovei $\boldsymbol{w}$ şi $[+]$ deasupra primului a, corectura $a$, cf. àpám (ostr.), ó á $\rho a ́ \mu$ (SеPт.), Aram (Ms.45).

Se observă că lecțiunea din text corespunde cel mai adesea sursei slavonești (OSTR.) și MS.45, iar adnotările marginale au fost preluate din Vulgata. Permutarea între text și glose este destul de frecventă în Ms.4389. Dacă în text este adoptată varianta de traducere din Vulgata, în nota marginală este consemnată varianta din versiunea slavonească, sau invers, de exemplu:
$I e z, 20,46$
"dumbrava cea mai mare Agheva",
despre miazäzi, cf. ad meridiani (vULG.) cf. àréва (osTR.)
Iez, 20, 47 „dumbrăvii de la amiazăzi”, cf. „saltui meridiano” (vULG.)
Aghévei, cf. доүвра́вt âге́вовł (OSTR.).

Un exemplu care scoate în evidență emendarea sursei principale cerută de însăși inconsecvența acesteia este cel al numelui $\operatorname{Oaram}$ (2.2.2., b, 11-12). În exemplul (11), acesta este transliterat în text după sursa slavonească și corectat marginal după cea grecească și după MS.45. În exemplul (12), forma numelui din text nu mai reflectă sursa principală (OSTR. Ápám), ci se explică prin preluarea automată a formei din versetul anterior; este corectată marginal, în conformitate cu toate cele trei izvoare.

Uneori, numele din nota marginală reproduce o precizare existentă chiar în OSTR. Este cazul de la $L e v, 18,21$ (cf. și Lev, 20, 2 și 3): „Și den sămînța ta să nu dai să slujască domnului Idolului și să nu apurci numele celui sfînt"; nota marginală este marcată cu patru săgeți orientate în jos: lui Moloh, cf. кNAsı

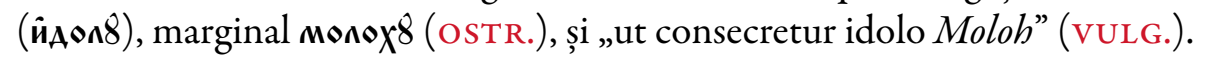

Nota marginală poate reproduce însă și o greșeală, prin preluarea unei variante eronate dintr-o sursă avută la îndemînă. De exemplu, numele Galatia $(1 M a c, 8,2$ : „Și auzi de războaiele lor și de bărbățiia cea bună care au făcut în Galátia”), adaptare a sursei slavonești (ranámeXł') sau latinești (Galatia), este glosat

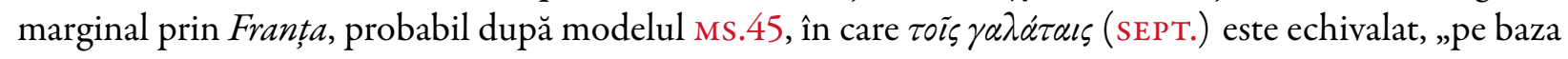


raționamentului galatean $=($ gal $)=$ franțoz" (Cândea, 1979, p. 222-223), prin franțozi: "Și au povestit lui războaiele lor și vitejiile carele au făcut întru franțozi”.

În cazul de mai jos, în mod straniu, deși VULG. conține un nume transparent, acesta nu este preluat de traducător, în notă, prin traducere, ci este reprodus cu alfabet latin:

Dan 11,16

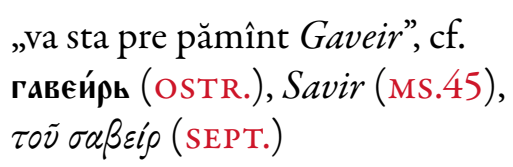

inclita, netradus și notat cu alfabet latin, după „terra inclyta” (vULG.), cf. inclitus 'vestit, renumit, slăvit'.

În contextul următor, varianta din sursa secundară este preluată ca notă explicativă: „Iar aceștia-s feciorii lui Sevegon: Aié și Onan; acesta Onan iaste care l-au aflat Iamin în pustie, cînd păștea boii tătîne-său, lui Sevegon" ( $F a c, 36,24)$; cuvîntul Iamín este glosat marginal (prin trei săgeți orientate cu vîrful în jos): „Iamin se înțealege «ape calde»”, cf. VULG. aquas calidas. Deși editorii seriei MLD au interpretat aici textul, transcriind numele cu inițială minusculă, este clar că traducătorul textului din MS. 4389 a interpretat cuvîntul ca pe un nume propriu, de vreme ce este scris cu majusculă, lecțiune care era întărită și de cea

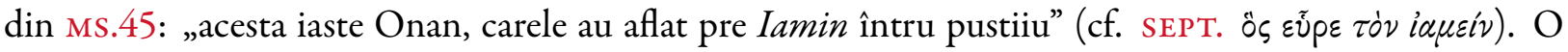
situație similară se întîlnește la 1Paral, 22, 9: „se va chiema numele lui Solomon”; antroponimul din text este explicat marginal (Solomon se înțeleage împăcare'), iar explicația este sugerată de varianta din VULG. („pacificus vocabitur”).

Sintagma acei de alt neam, din exemplele de mai jos, constituie traducerea termenului имоппємемьникъ 'de alt neam, străin' din OsTR.:

\begin{tabular}{|c|c|c|}
\hline $1 \operatorname{Reg}, 6,10$ & $\begin{array}{l}\text { acei de alt neam, cf. } \\
\text { ймоппєме́нмицы (OSTR.) }\end{array}$ & filistimleanii, cf. cei striini de feal (MS. 45 \\
\hline Avd, 19 & $\begin{array}{l}\text { filistimleanilor, cf. Philisthiim } \\
\text { (vULG.) }\end{array}$ & $\begin{array}{l}\text { celor de alt neam, cf. ймоппємеймики } \\
\text { (ostr.), cei de alt feal (MS.45) }\end{array}$ \\
\hline Iez, 25,15 & $\begin{array}{l}\text { cei de alt neam, cf. } \\
\text { иิмоппєме́ммицы (OSTR.) }\end{array}$ & palestineanii, cf. Palesthini (vULG.) \\
\hline Iez, 25, 16 & $\begin{array}{l}\text { celor de alt neam, cf. } \\
\text { ймоппємЕймики (OSTR.) }\end{array}$ & palistini, cf. Palesthinos (vULG.) \\
\hline Fac, 26, 14 & $\begin{array}{l}\text { filistimleanii, cf. фикисти́мове } \\
\text { (osTR.) }\end{array}$ & palestineanii, cf. Palesthini (vULG.). \\
\hline
\end{tabular}

Glosarea filistimleanii trimite la pasaje anterioare din text, unde etnonimul există ca atare $(J u d, 14,4 ; 1 R e g$, 6, 17 etc.); nota palestineanii este preluată după VULG..

\subsection{Emendări ale variantei textuale în raport cu norma lingvistică}

Astfel de note sînt rezultatul confruntării între norme lingvistice, consemnînd variante morfologice sau lexicale. Cele mai multe dintre ele se referă la articularea numelor proprii. În acord cu norma textului, în care predomină formele de genitiv-dativ cu articolul enclitic ale numelor de genul masculin terminate în - a la nominativ-acuzativ (Sisara, Iuda), pe marginea textului sînt emendate formele cu articol de genitivdativ antepus din text:
Jud, 5,30
"prada lui Sisar"
Sisárei, cf. Ms.45
2Paral, 25, 12 „feciorii lui Iúda”
Iúdei, cf. Ms.45.

De altfel, cu foarte puține excepții, în text și în comentariile exegetice de pe marginea lui este înregistrat cu preponderență uzul cu articol postpus la genitiv-dativ, de exemplu: „ieși stricăciune pre fruntea Oziei împărat” (2Paral, 26, 19), „trimease Senaherim să împute Ezéchiei” (2Paral, 32, 9), „Cartea 2 iar a vrăjmașilor Iudei” (1Ezdr, 4, 12), „Rugăciunea Ezechiei pentru cartea lui Senaherim” (Isa, 37, 16). În 
urma unor corecturi în text, apar și forme hibride de tipul „feciorii lui Iúdei” (Dan, 1, 6). Raportat la surse, formele Sisárei și Iúdei ar fi putut fi preluate și din MS.45, în care, deși predomină, formele cu articol postpus alternează cu cele cu articol antepus; vezi şi discuţia despre genitivul unor nume proprii masculine la Arvinte (1994, p. 7; 1991, p. 17), Ana-Maria Gînsac (MIlesCu, p. CCCX).

În cazul numelui mixt din Num, 32, 41 („Și mearse Iair, feciorul Manásiei, și luoă hodăile lor și le puse numele: Hodăile lui Iair"), traducătorul preia echivalarea din MS.45 (odăile lui Iair, cf. SEPT.

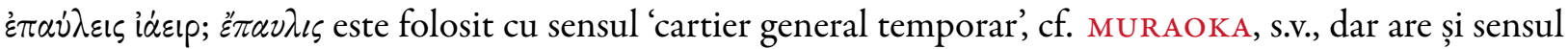
general 'casă la țară), dar cu fonetism regional: hodăile (pentru localizarea protezei lui $h$, vezi Gheție, 1978, p. 157-158). Varianta propusă marginal, satele, pe de o parte, corespunde lecțiunii din OSTR. (ć́na йấépoвa) și, pe de altă parte, are avantajul că este mai puțin marcată dialectal.

\subsection{Adnotări explicative ale variantei textuale în raport cu sistemul denominativ al limbii române}

Corespondentul românesc din epocă al unor toponime biblice este consemnat uneori în nota marginală, chiar și în cazurile în care nu corespunde formal niciuneia dintre surse, probabil pentru facilitarea înțelegerii textului (Ellada - Grecimea sau Țara Grecească, Țara Ethiopiei - Țara Harăpească $\breve{5}^{5}$, perși - cazîlbași, iudei-ovrei). Mai mult decît Milescu, traducătorul textului din MS.4389 pare să aibă mereu în vedere cititorul (vezi și notele care îi sînt direct adresate) și înțelegerea corectă a textului de către acesta. În acest scop, unele nume de țări și de popoare din text sînt glosate pe margine printr-un echivalent cunoscut la acea vreme în limba română:

\begin{tabular}{|c|c|c|}
\hline $\begin{array}{l}1 M a c, 6,5 \\
2 M a c, 9,1\end{array}$ & $\begin{array}{l}\text { Persida, cf. въ перси́д8 (ostr.), } \\
\text { in Perside (vulg.), la Persida } \\
\text { (MS.45) }\end{array}$ & Ţara Cazîlbăşască \\
\hline Iez, 38,5 & $\begin{array}{l}\text { persii, cf. Perse (vulg.), perse } \\
\text { (ostr.), Persi (Ms.45) }\end{array}$ & $\begin{array}{l}\text { cazîlbașii, din tc. kyzyl-baš 'cap roșu' } \\
\text { (DLR, s.v.) }\end{array}$ \\
\hline $1 M a c, 5,53$ & $\begin{array}{l}\text { "Tara Iúdei”, cf. земпю ió́, } \\
\text { (ostr.), „terram Iudam” } \\
\text { (vulg.), Iúdei (MS.45) }\end{array}$ & ovreiască \\
\hline Iez, 27,13 & Elláda, cf. ênáAa & $\begin{array}{l}\text { Grecimea, cf. Țara Grecească (Ms.45), } \\
\text { Grecia (vUlG.) }\end{array}$ \\
\hline Deut $, 2,8$ & 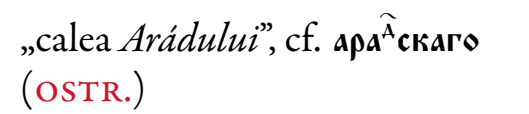 & $\begin{array}{l}\text { Harăpească, cf. „calea Arapcă” (MS.45), } \\
\text { dar „via campestrem” (vULG.) }\end{array}$ \\
\hline Fac, 2,13 & 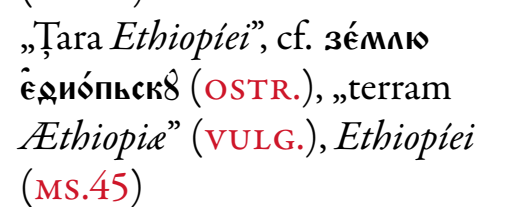 & Harăpească. \\
\hline
\end{tabular}

Alte nume de țări și de popoare din notele marginale sînt glosate potrivit surselor: „T,ara Jidovească” (1Mac,

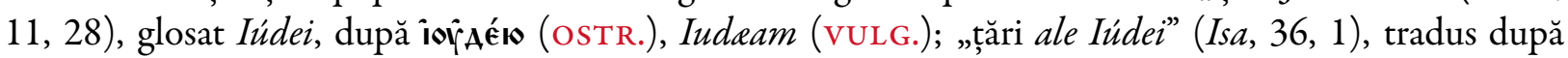
„civitates Iuda” (vUlg.), glosat jidovești după жидо́вски (оSTR.); „laturile jidovéști” (1Reg, 30, 14), glosat Iúdei după iốá́ncкïa (ostr.) și Iudam (vUlg.); Spániia (Iez, 30, 5), redat probabil după Ms.45 (spani), a fost glosat Aráviia, după аিравї̀ (OSTR.); „domnul ellinesc” (Dan, 10, 20), după еิмпикскь (OSTR.), a fost glosat prin adjectivul grecesc, după „princeps Grecorum” (vUlG.) sau grecilor (MS.45); „Tharac, împăratul murseanilor" (Isa, 37, 9), transpus după мйрскъ (OsTR.), a fost glosat prin etnonimul ethiopilor, după Ms.45 (ethiopilor) și vULG. („Tharaca rege Ethiopie”). Ca practică specifică Ms.4389, numele proprii din glose sînt preluate uneori în text fără a fi menționată, pe margine, varianta din sursa principală: cazîlbași pentru perși (Ier, 25, 24; Iez, 30, 5), jidovi și ovrei (învechit și regional) pentru iudei (DLR, s.v.). Înlocuirea

\footnotetext{
${ }^{5}$ Despre denumirile alcătuite din țară și un determinant adjectival format de la numele poporului care locuiește acea țară, vezi Arvinte (2008, p. 105-108).
} 
unui toponim atrage după sine substituirea etnonimului derivat de la toponim; astfel, Elada și elin sînt glosate Grecime și grec, iar Persida și persii sînt glosate Țara Cazîbășască și cazîlbași.

O explicitare prin echivalare cu un termen autohton a numelui din text o reprezintă nota marginală de la 3Reg, 8, 2: "Și se strînseră la împăratul Solomon tot nărodul lui Israil în luna lui athanín la praznic, că aceasta iaste luna a șaptea”, cf. ая.амим (OSTR.), Bethanim (VULG.), „întru luna thanin, întru praznic, aceasta iaste luna a opta" (MS.45, printr-o preluare eronată a copistului, probabil, cf. SEPT. ¿̇ं $\alpha \nu \varepsilon i \nu)$; în notă, numele lunii este echivalat prin septevrie (pentru explicații referitoare la luna Athanin în calendarul ebraic, vezi SEPT.NEC, vol. 2, p. 477).

\subsection{Clarificarea variantei textuale prin comentarii marginale cu caracter enciclopedic}

Întîlnit rar, acest tip de note marginale este destinat edificării cititorului asupra realităţilor culturale din textul sursă. În edițiile moderne ale Bibliei, astfel de comentarii apar la subsolul paginii sau juxtapuse numelui din text; vezi, în acest sens, edițiile ANANIA și SEPT.NEC.:

(1) $J u d, 3,8$

(2) Is.Nav, 18, 28 „împăratul Mijlocului Rîului și al Siriei", cf. церю cïрск8 в̈

MEжаоptчï̈ (OSTR.), „împăratul Mijlocul Rîului Siriei" (MS.45)

„Ievusul, carea iaste Ierusalimul”
Mijlocul Rîurilor iaste între apa Tígrului și a Efrathului; cheamă-se și Mesopo-

tamie, cf. „regis Mesopotamie” (vUlG.)

Vezi cum era numele Ierusalimului întîi.

În unele situații (2), fără ca nota marginală să constituie o explicație, traducătorul atrage atenția asupra unui aspect cultural pe care îl consideră important. Astfel de note nu sînt inspirate de sursele traducerii, iar modul formulării lor este asemănător cu cel din Îndreptarea legii, constituind un argument (după Ursu, 2003, p. 91-96) al paternității lui Daniil Panoneanul asupra textului din Ms.4389.

\section{Concluzii}

Traducerile românești ale Bibliei din secolul al XVII-lea prezintă numeroase probleme în privința adaptării numelor proprii din textele sursă. Unele dintre acestea sînt rezolvate în text, altele pe marginea lui. În privința onomasticii biblice, notele marginale din MS.4389 privesc raportul textului cu sursa principală (în general, corectarea erorilor din text), cu sursele secundare (semnalarea unor realități denominative diferite de sursa principală) și cu norma lingvistică a textului tradus (adaptări morfologice sau lexicale, actualizări potrivit sistemului denominativ al limbii țintă). Notele marginale din MS.4389 rezultă cel mai adesea din confruntarea dintre izvoarele folosite în traducere, fie că sursa principală este reflectată de text, iar cele secundare de note (cel mai adesea), fie, dimpotrivă, că textul reproduce o sursă secundară (de regulă, în astfel de cazuri, este preferat MS.45), iar notele, sursa principală (OSTR.).

Atunci cînd sursele exacte nu sînt menționate, numele din notele marginale pot constitui argumente importante în identificarea lor. O dovadă în această privință este numele Arie, notat pe marginea textului din MS.4389 în dreptul numelui Darie (1Mac, 12, 7; 12, 20). Comparînd mai multe ediții ale Vulgatei de la Anvers (vUlg.1565, vUlg.1587, vUlG.1592, vUlG.1603, vUlG.1645), considerate posibilele surse secundare ale acestui text, am observat că originalul utilizat în traducere nu este (numai) ediția din 1565 a Vulgatei de la Anvers (cf. Cândea, 1979, p. 131; Andriescu, 1988, p. 14), care are peste tot numele Dario, ci poate fi (și) o ediție de după 1590 (am consultat edițiile din 1592, 1603, 1645), care conține numele Ario / Arius (vezi 2.2.1. b, 11).

În privința numelor de țări și de popoare cu o utilizare frecventă (Ellada - Grecimea, Țara Grecească, Țara Ethiopiei - Țara Harăpească, Persida - Țara Cazîlbăşsască, persi - cazîlbași, iudei - ovrei etc.), actualizarea, conform uzului din epocă, indică atenția pe care o acorda traducătorul inteligibilității textului.

Spre deosebire de Nicolae Milescu Spătarul, care urmează strict, pînă la literalism, izvorul principal, traducătorul textului din MS.4389 are un stil de traducere orientat atît spre text (pentru a obține o traducere care să corespundă canoanelor, lucru demonstrat de utilizarea mai multor izvoare), cît și spre cititor. 
Această a doua tendință este demonstrată de comentariile care îi atrag atenția cititorului asupra aspectelor considerate importante, de îndepărtarea (uneori) de litera textului, chiar de faptul că, acolo unde versiunea din MS. 45 i se pare mai cursivă, nu ezită să o preia pe aceasta, chiar dacă în notă o menționează și pe cea din izvorul principal. Desigur, variantele de traducere consemnate în note ar putea să susțină și afirmația din proimion referitoare la cunoașterea imperfectă a limbilor de cultură, dar credem că, mai degrabă, notele marginale reprezintă expresia dorinței traducătorului de a obține un text cît mai complet, dar în același timp canonic și inteligibil pentru cititor.

\section{Bibliografie}

\section{A. Studii}

Andriescu, Al. (1988). Locul Bibliei de la București în istoria culturi, literaturii și limbii române literare, în MLD, Pars I, Genesis, Editura Universităţii „Alexandru Ioan Cuza”, Iași, p. 7-45.

Arvinte, V. (1991). Studiu lingvistic asupra cărțtii a doua (Ieşirea) din Biblia de la București (1688), in comparație cu ms. 45 și cu ms. 4389, în MLD, Pars II, Exodus, p. 1-51.

Arvinte, V. (1994). Studiu lingvistic asupra cărții a patra (Numerii) din Biblia de la București (1688), in comparație cu ms. 45 și cu ms. 4389, în MLD, Pars IV, Leviticus, p. 1-44.

Arvinte, V. (2008). Român, românesc, România. Studiu filologic, ediția a III-a, Casa Editorială „Demiurg”, Iași.

Catană-Spenchiu, A. (2013). Tipuri de glose in Biblia de la Blaj (1795), în Flores philologia. Omagiu profesorului Eugen Munteanu, la împlinirea vârstei de 60 de ani, editat de A. Catană-Spenchiu, I. Repciuc, F. Faifer, Editura Universităţii „Alexandru Ioan Cuza", Iași, p. 209-223.

Cândea, V. (1979). Rațiunea dominantă. Contribuții la istoria umanismului românesc, Editura Dacia, Cluj-Napoca.

Gafton, Al. (2005). După Luther. Traducerea vechilor texte biblice, Editura Universității „Alexandru Ioan Cuza”, Iași.

Gafton, Al. (2012). De la traducere la norma literară. Contribuția traducerii textului biblic la constituirea vecbii norme literare, Editura Universității „Alexandru Ioan Cuza”, Iaşi.

Gheție, I. (1978). Baza dialectală a românei literare, Editura Academiei Române, București.

Gînsac, A.-M. (2012a). Despre glosarea numelor proprii in primele manuscrise românești ale Bibliei, în Munteanu, E. (coord.), Receptarea Sfintei Scripturi între filologie, hermeneutică și traductologie. Lucrările Simpozionului Național „Explorări în tradiția biblică românească și europeană”, Iaşi, 4-5 noiembrie 2011, Editura Universității „Alexandru Ioan Cuza”, Iași, p. 219-228.

Gînsac, A.-M. (2012b). Despre echivalarea toponimelor biblice descriptive în limba română, în „Studii și cercetări lingvistice”, lxiii, 1, p. 121-135.

Gînsac, A.-M. (2013). Les notes marginales sur le texte révisé de l'Ancien Testament traduit par Nicolae Milescu en XVIIe siècle (ms. 45), comunicare susținută la al XXVII-lea Congres Internațional de Lingvistică și Filologie Romanică, Nancy, iulie 2013.

Merlo, R. (2018). Sulle glosse parententiche nel Reglement organicesc a Moldovei (1831), în Studii romanice. Omagiu profesorilor Florica Dimitrescu și Alexandru Niculescu la 90 de ani, vol. 2, volum editat de C. Lupu, Al. Ciolan, Al. Zuliani, Editura Universităţii din București, București, p. 657-693.

Roques, M. (1908). Palia d'Orăştie (1581-1582) : préface et livre de la Genèse, thèse complémentaire présentée à la Faculté des lettres de l'Université de Paris, series „Les premières traductions roumaines de l'Ancien Testament”, 1, [s. n.], Paris.

Soare, L. (2015). Învățătură pentru ferirea și doftoria boalelor (1816). Considerații asupra gloselor, în „Diacronia”, 1, 13 ian., 2015, A9, Crossref.

Șesan, D. (2002). Glosele marginale din Noul Testament de la Bălgrad (1648) siproblema seriilor sinonimice, în Noul Testament de la Bălgrad (1648). Carte de limbă și simțire românească, Editura „Pentru viață”, Brașov, p. 59-167.

Ștrempel, G. (1987). Catalogul manuscriselor românești, vol. 3, Editura Științifică și Enciclopedică, București.

Thomson, F.J. (1998). The Slavonic Translation of the Old Testament, in The Interpretation of the Bible. The International Symposium in Slovenia, editat de J. Krašovek, Sheffield Academic Press, Sheffield.

Țepelea, G.F. (1963). Cîteva precizări in legătură cu izvoarele și glosele Noului Testament de la Bălgrad (1648), în „Limba română", XII, 3, p. 274-282.

Ungureanu, M. (2015). Despre notele marginale din prima versiune românească integrală a Septuagintei (Ms. 45 de la Biblioteca Filialei din Cluj a Academiei Române), în „Diacronia”, 2, 17 iul., A23, Crossref.

Ursu, N. A. (2003). Contribuțtii la istoria culturii românești in secolul al XVII-lea. Studii filologice, Editura Cronica, Iași.

\section{B. Surse}

ANANIA = Biblia sau Sfinta Scriptură, versiune întocmită de I.P.S. Bartolomeu Valeriu Anania, Editura Institutului Biblic și de Misiune al Bisericii Ortodoxe Române, București, 2001.

DLR = Diç̦ionarul limbii române, ediție anastatică [după Diç̦ionarul limbii române (DA) și Diç̦tionarul limbii române (DLR), București, Librăriile Socec \& Comp. și Sfetea, 1913-2005], 19 vol., Editura Academiei Române, București, 2010. 
MILESCU = Vechiul Testament - Septuaginta. Versiunea lui Nicolae Spătarul Milescu (Ms. 45 de la Biblioteca Filialei din Cluj a Academiei Române), ediție de E. Munteanu (coord.), A.-M. Gînsac, A.-M. Minuț, L.-G. Munteanu, M. Ungureanu, Editura Universității „Alexandru Ioan Cuza”, colecția „Fontes Traditionis”, Iași, 2016.

MLD = Monumenta lingue Dacoromanorum. Biblia 1688, 24 vol., Editura Universității „Alexandru Ioan Cuza”, Iași, 19882015.

MS.4389 = Manuscrisul românesc nr. 4389, Biblioteca Academiei Române, București.

Ms.45 = Manuscrisul românesc nr. 45, Biblioteca Academiei Române - Filiala Cluj.

MURAOKA = Takamitsu Muraoka, A Greek-English Lexicon of the Septuagint, Peeters, Louvain-Paris-Walpole, 2009.

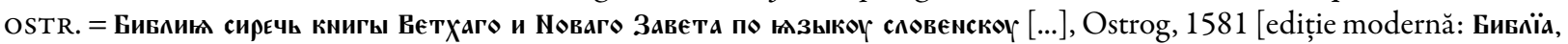

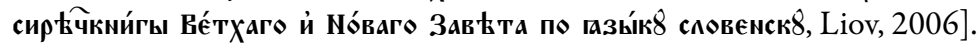

PO = Palia de la Orăştie (1582). I. Textul, ediție întocmită de V. Arvinte, I. Caproşu, Al. Gafton, Editura Universităţii „Alexandru Ioan Cuza”, Iași, 2005.

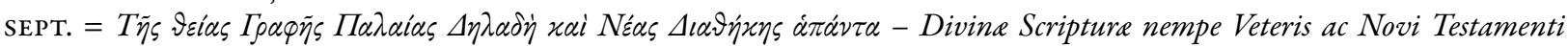
omnia Græce a viro doctissimo recognita et emendata, variisque lectionibus aucta et illustra, apud Andreæ Wecheli hæredes, Frankofurti ad Moenum, 1597.

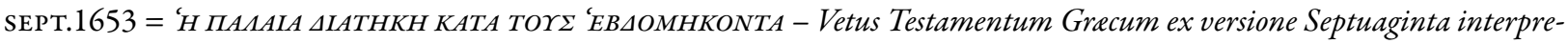
tum, iuxta Exemplar Vaticanum Romæ editum, Accuratissime [...], Excudebat Rogerus Daniel, Londini, 1653.

SEPT.NEC = Septuaginta, 6 vol., Colegiul „Noua Europă”, Polirom, București-Iași, 2005.

VULG. = Biblia ad vetustissima exemplaria castigata, quid in horum Bibliorum castigatione præstitum sit, subsequens præfatio latius indicabit, Ex officina Christophori Plantini, Antverpiæ, 1565.

vULG.1587 = Biblia sacra, quid in hac editione a Theologis Lovaniensibus præstitum sit, paulo post indicatur, Ex officina Christophori Plantini, Architypographi Regii, Antverpiæ, 1587.

vulg.1592 = Biblia Sacra Vulgate editionis Sixti Quinti Pont. Max. iussu recognita atque edita, Ex Typographia Apostolica Vaticana, Christophori Plantini, Romæ, 1592.

vulg.1603 = Biblia Sacra Vulgate editionis Sixti V. Pont. Max. iussu recognita atque edita, Ex officina Plantiniana, Apud Ioannem Moretum, Antverpix, 1603.

vulg.1645 = Biblia Sacra Vulgate editionis Sixti V. Pont. Max. iussu recognita atque edita, Ex officina Plantiniana, Antverpiæ, 1645. 